\title{
Modeling Academic Writing for University Students
}

\author{
Aunurrahman ${ }^{1}$; Fuad Abdul Hamied ${ }^{2}$; Emi Emilia ${ }^{3}$ \\ IKIP-PGRI Pontianak, Pontianak, Indonesia ${ }^{1 *}$ \\ Universitas Pendidikan Indonesia, Bandung, Indonesia ${ }^{2}$ \\ Universitas Pendidikan Indonesia, Bandung, Indonesia ${ }^{3}$ \\ yarrha@gmail.com
}

\begin{abstract}
A good piece of academic writing is achieved through hard work and dedication. The hard work and dedication require the academic writing basic knowledge mastery. Yet, this is not an easy task for university students. This conceptual paper proposes how to model academic writing for university students in the Indonesian context. The paper, firstly, introduces the concept of academic writing. The concept of academic writing is more than just academic writing genres with the linguistic features. It also covers intellectual standards, fallacies in reasoning, and ethics of academic writing that realize the quality of the students' academic thinking. The concept, later on, guides a lecturer to modeling academic writing. The modeling stage is a part of the genre-based approach derived from systemic functional linguistics. Modeling is about how a lecturer should be able to model good academic writing and good critical thinking. An instance of model text is provided as an example of the modeling strategy.
\end{abstract}

Keywords: genre-based approach, modeling, academic writing, critical thinking

\section{INTRODUCTION}

University students should be able to think and to write academically. Thinking and writing in an academic setting are about how university students present their reasons (Elbow, 1991). If a student is asked about his or her reason applying to a university, several responses can be expected. Two of them are "my father wants me to do this" and "I have an interest in this field of study that I think is good for my future career." The first response sounds that the student unlikely has an internal motivation to apply to the university and unlikely will be a successful student. On the other hand, the second response shows an expected reason of a university student where the student's interest is in accordance with the field of study of the university. Students who have no sufficient knowledge to do an academic reasoning will present their reasons similar with the first response. It is a task for lecturers to assist the students in achieving good reasoning skills at the university level (see Fischer et al., 2014).

A medium for students to learn the reasoning skills is academic writing (Swartz \& McGuinness, 2014; Vyncke, 2012). The government of Indonesia realized the importance of academic writing and suggested every university in
Indonesia utilizes academic writing and a publication of it as a part of the university students' requirements in completing their studies (Akuntono, 2012). Still, mastery of academic writing is not an easy task. Indonesian students are known to have limitations in academic writing (Hardono, 2016; Nugraha, 2015).

The main challenge is how to write a specific genre of academic writing at the university level with various linguistic features. A genre-based approach is an approach that addresses this issue. The approach derived from systemic functional linguistics and commonly used in the teaching of literacy, including writing (Christie \& Derewianka, 2010; Derewianka, 2012). It is developed in Australia by Sydney school and nowadays practiced worldwide (Derewianka, 2003; Emilia, 2005; Swales, 2012). Accordingly, the paper shares a modeling strategy to teaching academic writing for the university students that the writers found worked in Indonesian context (see Aunurrahman, Hamied, \& Emilia, 2016). The discussion of the conceptual paper begins from the concept of academic writing followed by the modeling strategy to teaching academic writing. Due to the nature of a conceptual paper (see Gilson \& Goldberg, 2015), the paper only discusses existing literature and links them to a modeling strategy that worked in Indonesian context.

\section{ACADEMIC WRITING}

Academic discourse is about presenting arguments with the reasons and the evidence, which is also the main purpose of literacy (Elbow, 1991). These will show how critical university students are when they deal with a certain issue. This paper views critical thinking along with the reasoning skills as part of academic discourse, which makes the term critical thinking in this paper is used interchangeably with the term reasoning skills. This academic discourse and or critical thinking can be reflected from the students' academic writing (Ennis, 1993).

Academic writing has competencies that are required to achieve good academic discourse. The competencies are genres that can organize and reflect the students' thinking and reasoning skills along with the various linguistic features that represent the skills aforementioned 
(Bruce, 2008; Kay \& Dudley-Evans, 1998). A genre under systemic functional linguistics has stages and social functions (Martin, 1992, 2010). The genre that is suitable for a higher education purpose is argumentative writing, which has two basic genres. The genres are exposition and discussion genres with 'persuading that' and 'persuading to' functions (Coffin, 2004; Martin, 1992).

The genres mainly have three important elements. The elements are thesis - the main idea argued in a writing; arguments - elaboration of arguments that support the main idea; and reiteration of thesis - a summary of the writing followed by a recommendation if necessary (Coffin, 2004; Martin, 2006). These elements are stitched and structured into a particular pattern known as Thematic progression. A common Thematic progression used for argumentative writing is derived Themes where a Theme of a clause or a paragraph introduces several points of information that become Themes in the clauses or paragraphs that follow (Eggins, 2004; Emilia, 2014). This, according to critical thinking proponents, is called as information-organizing skills (Lipman, 2003).

Besides information-organizing skills, university students should also be able to use various linguistic features that can enrich their argumentative writing. Some features of argumentative writing, according to Derewianka (1990), are: (1) generalized participants - human or abstract; (2) technical terms related to the issue argued; (3) timeless present tense in previewing position and points of information; (4) passive voice to structure a writing; (5) nominalization to reflect objectivity; (6) conjunctions that can reflect reasoning; and (7) logic and evidence (pp. 76-78). These features are also called as academic language (Schleppegrell, 2009). Most of the features are related to structure an argumentative writing, except for logic and evidence features. These features should be defined further.

Logic and evidence, under the critical thinking concept, are parts of intellectual standards, which are the standards that determine the quality of one's critical thinking (Paul \& Elder, 2001, 2002). The intellectual standards, according to Elder \& Paul $(2010,2013)$, are clarity, accuracy, precision, relevance, depth, breadth, logic, and fairness. These standards should be reflected in the argumentative writing mainly when presenting a point of information. However, employing intellectual standards are not easy; students should also know fallacies in reasoning or critical thinking. Fallacies are invalid arguments (Robinson, 2011; Rudinow \& Barry, 2008) that can weaken one's argumentative writing. Several fallacies, according to Kurfiss (1997), are: (1) provincialism - base argument on experience; (2) Ad hominem - confront a person's character instead of the argument presented; (3) false dilemma; (4) hasty conclusion or generalization; and (5) begging the question, circularity (pp. 15-16). Another important aspect that should be paid attention is ethics of academic writing where students should know how to utilize references to support their writing. Some ways to utilize reference are by using in-text references such as quotation, paraphrase, and summary that should be followed by listing the references (Jones, 2011; Oshima \& Hogue, 1999).

The concept of academic writing discussed in this paper covers the genre in academic writing, that is, argumentative writing with its Thematic progression pattern and linguistic features that can structure and reflect one's critical thinking. In relation to the quality of the critical thinking, university students are required to know about intellectual standards, fallacies in reasoning, and ethics of academic writing. Without these aspects, university students may not do their best in providing good quality of reasoning. Moreover, lecturing may be an easy way to introduce this concept of academic writing. However, it will not work well without a proper strategy. The genre-based approach offers a way to solve that issue and that is modeling, which is a part of the genre-based approach teaching stages. This will be discussed further in the following section.

\section{MODELING ACADEMIC WRITING FOR UNIVERSITY STUDENTS}

A genre-based approach, derived from systemic functional linguistics, commonly has four important stages. The stages are building knowledge of field where students build their knowledge on a certain topic that will be argued, modeling a text type that will be written, joint construction of a text by the students with the help of the teacher or lecturer, and independent construction of a text by the students independently. These stages are commonly practiced in Indonesia (Emilia, 2012). In order these stages can work effectively, principles of the genre-based approach should be mastered. The principles are: (1) focusing on text, meaning and choice; (2) focusing on purpose; and (3) explicit teaching under the guidance of the teacher in apprenticeship (Derewianka, 2003; Emilia, 2005). This paper limits its focus on the modeling stage of the genre-based approach where the explicit teaching is deeply needed especially by the university students who have insufficient knowledge of academic writing and critical thinking. In fact, critical thinking is suggested by the proponents to be introduced earlier before it is practiced in a certain context (see Ennis, 1989). 
In modeling stage, the students are expected to model expert texts. In this occasion, modeling should be more than providing model texts of academic writing. A lecturer should also provide model texts of good critical thinking. In order to provide a good modeling stage, the lecturer should master the basic concept of academic writing and critical thinking that are discussed in the previous section.

Based on the concept of the academic writing, important points that should be modeled are the genres that are in accordance with academic writing along with the linguistic features. In relation to reasoning skills or critical thinking skills, intellectual standards, fallacies in reasoning, and ethics of academic writing should also be modeled. Due to the limited space, this paper provides only an instance to show how modeling should be conducted. The model text in Table 1 covers a genre in academic writing with its linguistic features. The model text is as follows:

\begin{tabular}{|c|c|c|}
\hline $\begin{array}{l}\text { Schematic } \\
\text { Structure }\end{array}$ & Text & Linguistic features \\
\hline $\begin{array}{l}\text { The text } \\
\text { has no } \\
\text { reiteration } \\
\text { of thesis }\end{array}$ & $\begin{array}{l}\text { There are four things a } \\
\text { young child ought to learn } \\
\text { about fishing his first time } \\
\text { out. First, hooks are sharp. } \\
\text { Demonstrate this by } \\
\text { lightly pressing the point } \\
\text { against the fleshy part of } \\
\text { his thumb. Second, a pole } \\
\text { is held in a certain way } \\
\text { (usually at the end in two } \\
\text { hands, one above the } \\
\text { other). Third, noise } \\
\text { frightens the fish away. } \\
\text { Fourth, the fisherman } \\
\text { must be patient. Perhaps } \\
\text { the best way to teach } \\
\text { patience is to be patient } \\
\text { yourself, since his attitude } \\
\text { will depend to a } \\
\text { considerable extent on } \\
\text { how you behave. }\end{array}$ & $\begin{array}{l}\text { Impersonal voice } \\
\text { mainly present } \\
\text { testimony } \\
\text { connectives (first, } \\
\text { second, third, } \\
\text { fourth) structuring } \\
\text { the arguments with } \\
\text { elaboration on the } \\
\text { first and fourth } \\
\text { arguments connective: } \\
\text { logical con } \\
\text { since perhaps }\end{array}$ \\
\hline
\end{tabular}

(The model text was written by Schwartz and cited in Bloor

\& Bloor, 2004, p. 11)

Model text 1 (see Table 1) covers the schematic structure and linguistic features of a simple exposition text as the text only consists of a paragraph. It will be a good example for beginners who are new to this genre. A suggestion for lecturers is to use authentic texts as the model texts. This can be difficult for the first time for beginners but it will be more beneficial as authentic texts will help the students to get accustomed to the target language (Lingzhu \& Yuanyuan, 2010; Peacock, 1997). The model text provided should be followed by an explanation of the schematic structure and linguistic features of an exposition genre. At this point, Thematic progression, intellectual standards, fallacies in reasoning, and ethics of academic writing should also be introduced to the students even though the model text is not fully sufficient to do so. Another model text should help the students to get in touch further with those features.

The last thing to do in the modeling stage is to evaluate the students' knowledge regarding the aspects of academic writing and critical thinking that build the academic writing competencies. An instance of an evaluation in the modeling stage is shown in Table 2 as follows:

Table 2: The Instance of an Evaluation in Modeling Stage

\section{Instruction: Identify the schematic structure, linguistic features, intellectual standards, fallacies, and ethics of academic writing of the text provided below!}

\begin{tabular}{l|l|l}
\hline $\begin{array}{l}\text { Schematic } \\
\text { Structure }\end{array}$ & Text & $\begin{array}{l}\text { Linguistic features / Intellectual } \\
\text { standards / Fallacies / Ethics of } \\
\text { academic writing }\end{array}$ \\
\hline $\begin{array}{l}\text { Let the } \\
\text { students } \\
\text { identify } \\
\text { the } \\
\text { schematic } \\
\text { structure } \\
\text { of the text }\end{array}$ & $\begin{array}{l}\text { Put a model } \\
\text { text here }\end{array}$ & $\begin{array}{l}\text { Let the students identify the } \\
\text { linguistic features, intellectual } \\
\text { standards, fallacies, and ethics of } \\
\text { academic writing }\end{array}$ \\
\hline
\end{tabular}

In accordance with Table 2, the evaluation of the students' knowledge regarding the aspects of academic writing and critical thinking can be done by providing an expert text, which should be an authentic one. Besides providing an expert text, two columns or even more columns (see Table 2) can be provided for the students to fill the schematic structure, linguistic features, intellectual standards, fallacies, and ethics of academic writing that can be identified in the text as they will be instructed to identify them in the text.

In conclusion, the concept of academic writing and critical thinking eventually are important to be provided earlier as it will be a guideline for a lecturer to conduct a modeling stage. A diagnostic test before the modeling should also assist the lecturer to encounter the students' weaknesses in academic writing. Preparing several model texts is crucial to address every aspect of academic writing and critical 
thinking. Surely, an evaluation will help the lecturer to see the students' progress in learning through the modeling stage. Different strategies can be applied depend on the students' needs.

\section{CONCLUSION}

A lecturer may find that every expert or model text has its own features and limitations. That means one model text is not sufficient to introduce every aspect of academic writing. It requires several instances to get in touch with every aspect of it. Then, a successful modeling stage depends on the lecturer's mastery of the basic knowledge of academic writing and critical thinking. The concept of the academic writing and the modeling strategy can be modified depend on the need of the students. In order to provide a good modeling stage, a diagnostic test can assist the lecturer to find the students' weaknesses. Providing model texts that address the aspects of academic writing, critical thinking, and the students' weaknesses are expected to make the students better in academic writing

\section{REFERENCES}

Akuntono, I. (2012, February 3). Ini alasan mahasiswa wajib publikasi makalah. KOMPAS.com. Retrieved from http://enodukasi.kompas.com/read/2012/02/03/15160 740/Ini.Alasan.Mahasiswa.Wajib.Publikasi.Makalah

Aunurrahman, Hamied, F. A., \& Emilia, E. (2016). Exploring an academic writing class in an Indonesian university context. Language Circle: Journal of Language and Literature, 11(1), 1-12.

Bloor, T., \& Bloor, M. (2004). The Functional Analysis of English: A Hallidayan Approach (2nd ed.). London, UK: Arnold.

Bruce, I. (2008). Academic writing and genre: A systematic analysis. New York, NY: Continuum.

Christie, F., \& Derewianka, B. (2010). School discourse learning to write across the years of schooling. London; New York: Continuum.

Coffin, C. (2004). Arguing about how the world is or how the world should be: the role of argument in IELTS tests. Journal of English for Academic Purposes, 3(3), 229-246. http://doi.org/10.1016/j.jeap.2003.11.002 Derewianka, B. (1990). Exploring How Texts Work. Rozelle, NSW: Primary English Teaching Association

Derewianka, B. (2003). Trends and issues in genre-based approaches. RELC Journal, 34(2), 133-154. http://doi.org/10.1177/003368820303400202

Derewianka, B. (2012). Knowledge about language in the Australian curriculum: English. Australian Journal of Language and Literacy, 35(2), 127-146. Retrieved from http://ro.uow.edu.au/sspapers/129/

Eggins, S. (2004). An introduction to systemic functional linguistics (2nd ed.). New York: Continuum.

Elbow, P. (1991). Reflections on academic discourse: How it relates to freshmen and colleagues. College English, 53(2), 135. http://doi.org/10.2307/378193

Elder, L., \& Paul, R. (2010, October). Universal intellectual standards. Retrieved December 6, 2014, from http://www.criticalthinking.org/pages/universalintellectual-standards/527

Elder, L., \& Paul, R. (2013). Critical thinking: Intellectual standards essential to reasoning well within every domain of human thought. Journal of Developmental Education, 36(3), 34-35.

Emilia, E. (2005). A critical genre-based approach to teaching academic writing in a tertiary EFL context in Indonesia (Unpublished Dissertation). The University of Melbourne, Melbourne. Retrieved from https://minerva-

access.unimelb.edu.au/handle/11343/39548

Emilia, E. (2012). Pendekatan genre-based dalam pengajaran bahasa Inggris: Petunjuk untuk guru (2nd ed.). Bandung, Indonesia: Rizqi Press.

Emilia, E. (2014). Introducing functional grammar. Bandung, Indonesia: Pustaka Jaya.

Ennis, R. H. (1989). Critical thinking and subject specificity: Clarification and needed research. Educational Researcher, 18(3), 4-10. http://doi.org/10.3102/0013189X018003004

Ennis, R. H. (1993). Critical thinking assessment. Theory into Practice, 32(3), 179-186.

Fischer, F., Kollar, I., Ufer, S., Sodian, B., Hussmann, H., Pekrun, R., ... others. (2014). Scientific reasoning and argumentation: Advancing an interdisciplinary research agenda in education. Frontline Learning Research, 2(3), 28-45. Retrieved from http://journals.sfu.ca/flr/flr/index.php/journal/article/v iew/96

Gilson, L. L., \& Goldberg, C. B. (2015). Editors' comment: So, what is a conceptual paper? Group \& Organization Management, 40(2), 127-130. https://doi.org/10.1177/1059601115576425

Hardono, I. (2016, February 22). Faktanya... Pelajar Indonesia keteter dalam "academic writing"! KOMPAS.com. Retrieved from http://edukasi.kompas.com/read/2016/02/22/0529002 1/Faktanya.Pelajar.Indonesia.Keteter.dalam.Academic .Writing.

Jones, L. R. (2011). Academic integrity \& academic dishonesty: A handbook about cheating \& plagiarism (Revised \& expanded edition). Melbourne, Florida: Florida Institute of Technology. Retrieved from https://www.fit.edu/current/documents/plagiarism.pdf

Kay, H., \& Dudley-Evans, T. (1998). Genre: What teachers think. ELT Journal, 52(4), 308-314. 
http://doi.org/10.1093/elt/52.4.308

Kurfiss, J. G. (1997). Critical thinking: Theory, research, practice, and possibilities. Washington, D.C.: Graduate School of Education and Human Development, George Washington University.

Lingzhu, J., \& Yuanyuan, Z. (2010). The use of authentic materials in teaching EFL listening. Humanising Language Teaching Magazine for Teachers and Teacher Trainers, 12(4). Retrieved from http://www.hltmag.co.uk/aug10/mart03.htm

Lipman, M. (2003). Thinking in education (2nd ed.). New York, US: Cambridge University Press. Retrieved from http://dx.doi.org/10.1017/CBO9780511840272

Martin, J. R. (1992). English text: System and structure. Philadelphia: John Benjamins Pub. Co.

Martin, J. R. (2006). Mentoring semogenesis: "Genrebased" literacy pedagogy. In F. Christie (Ed.), Pedagogy and the Shaping of Consciousness: Linguistic and Social Processes (pp. 123-155). London, UK: Continuum.

Martin, J. R. (2010). Semantic variation - modelling realisation, instantiation and individuation in social semiosis. In J. R. Martin \& M. Bednarek (Eds.), New Discourse on Language Functional Perspectives on Multimodality, Identity, and Affiliation (pp. 1-34). New York, NY: Continuum.

Nugraha, A. K. E. (2015, August 26). Mahasiswa Indonesia masih lemah menulis karya ilmiah. Rakyatku.Com. Retrieved from http://rakyatku.com/2015/08/26/edukasi/mahasiswaindonesia-masih-lemah-menulis-karya-ilmiah.html

Oshima, A., \& Hogue, A. (1999). Writing academic English (3rd ed.). New York: Addison Wesley Longman.

Paul, R., \& Elder, L. (2001). How to detect media bias \& propaganda in national and world news. Dillon, California: Foundation for Critical Thinking.

Paul, R., \& Elder, L. (2002). Critical thinking: Tools for taking charge of your professional and personal life. Upper Saddle River, NJ: Financial Times/Prentice Hall.

Peacock, M. (1997). The effect of authentic materials on the motivation of EFL learners. ELT Journal, 51(2), 144-156. Retrieved from http://eltj.oxfordjournals.org/content/51/2/144.short

Robinson, S. R. (2011). Teaching logic and teaching critical thinking: Revisiting McPeck. Higher Education Research \& Development, 30(3), 275-287. http://doi.org/10.1080/07294360.2010.500656

Rudinow, J., \& Barry, V. E. (2008). Invitation to critical thinking (6th ed). Australia; Belmont, CA: Thomson Wadsworth.

Schleppegrell, M. J. (2009). Language in academic subject areas and classroom instruction: What is academic language and how can we teach it? Presented at the Workshop on the Role of Language in School Learning: Implications for Closing the Achievement Gap, October 15-16, Hewlett Foundation, Menlo Park, CA. Retrieved from https://www.mydigitalchalkboard.org/cognoti/content/ file/resources/documents/98/98c3e7f4/98c3e7f49b44e aa5ee60b45939df619b4593afc7/Schleppegrell.pdf

Swales, J. M. (2012). A text and its commentaries: Toward a reception history of "Genre in three traditions"(Hyon, 1996). Ibérica: Revista de La Asociación Europea de Lenguas Para Fines Específicos (AELFE), (24), 103-115. Retrieved from http://dialnet.unirioja.es/servlet/articulo?codigo $=4106$ 624

Swartz, R., \& McGuinness, C. (2014). Developing and assessing thinking skills: The international baccalaureate project 2014. The International Baccalaureate Organisation.

Vyncke, M. (2012, September). The concept and practice of critical thinking in academic writing: An investigation of international students' perceptions and writing experiences (Thesis). King's College, London. Retrieved from http://englishagenda.britishcouncil.org/sites/ec/files/ M\%20VYNCKE_0.pd 